\title{
Pemberian kecambah kacang kedelai terhadap kadar malondialdehid (MDA) dan superoxide dismutase (SOD) tikus Sprague Dawley hiperkolesterolemia
}

The effect of soybean sprout (Glycine Max) to levels of malondialdehyde (MDA) and superoxide dismutase (SOD) of male Sprague Dawley rats hypercholesterolemic

\section{Denny Indra Setiawan ${ }^{1}$, Kusmiyati Tjahyono ${ }^{2}$, Diana Nur Afifah ${ }^{3}$}

Jurusan Gizi Politeknik Kesehatan Kementerian Kesehatan Gorontalo

Program Studi Ilmu Biomedik, Fakultas Kedokteran Universitas Diponegoro

Program Studi Ilmu Gizi, Fakultas Kedokteran Universitas Diponegoro

\begin{abstract}
Background: Consumption of foods high in fat that happens in society can cause free radicals and trigger oxidative stress that result in the accumulation of fat cells in the adiposit, cells damage and even cells death. Antioxidant activity that originates from food in the body, depends on the number of substances that can be absorbed and used to metabolism process. The selection of groceries that right can be alternatives management in hyperlipidemia. Soybean sprouts have properties that neutralize free radicals cause hyperlipidemia and cardiovascular diseases because it is an antioxidant compounds. Objective: The aim of this study was to determine the effect of soybean sprouts (Glycine Max) to levels of MDA and levels of SOD of male Sprague Dawley rats. Methods: Research laboratory tests design post only controlled group design. The sample was 30 tailed rat Rattus norvegicus species Sprague Dawley. The rat 8-10 weeks and samples to be divided into 5 group. Group 1 was normal rat without treatment; groups II are hypercholesterolemic rat without treatment; groups III are hypercholesterolemic rat with treatment sprouts soybeans 0,53 g; group IV are hypercholesterolemic rat with treatment sprouts soybeans 1,06 g; the group V are hypercholesterolemic rat with treatment sprouts soybeans 2,12 g and all groups are treatment for 4 week. Results: After four weeks of treatment, decline MDA levels in the hypercholesterolemic rat. Doses the provision of sprouts soybean 2,12 g/day is doses most effective shown the significant differences $(p<0.05)$ between the treatment group first to the treatment thrid group. Statistical analysis to SOD levels show differences meaningful in all the treatment group $(p<0.05)$. Doses the provision of sprouts soybean $2,12 \mathrm{~g} /$ day proven effective against elevated levels of sod who demonstrated by the significant differences $(p=0,004)$ between the treatment group $1(X)$ to the treatment group $3\left(X_{3}\right)$. Conclusions: Doses sprouts 2,12 $\mathrm{g}$ is doses optimal in preventing elevated levels of MDA and help improve levels of SOD hypercholesterolemic Sprague Dawley rats.
\end{abstract}

KEY WORDS: hypercholesterolemic; levels of MDA; levels of SOD; soybean sprout

\begin{abstract}
ABSTRAK
Latar belakang: Konsumsi makanan tinggi lemak dapat menyebabkan terbentuknya radikal bebas sehingga memicu terjadinya stres oksidatif yang berakibat terjadinya akumulasi sel lemak di jaringan adiposit, kerusakan bahkan kematian sel. Aktivitas antioksidan yang berasal dari makanan yang masuk di dalam tubuh, sangat tergantung dari jumlah zat yang dapat diserap dan digunakan untuk proses metabolisme. Pemilihan bahan pangan yang tepat dapat menjadi alternatif dalam penatalaksanaan hiperlipidemia. Kecambah kacang kedelai memiliki sifat menetralkan radikal bebas penyebab hiperkolesterolemia karena mengandung senyawa antioksidan. Tujuan: Mengetahui pengaruh pemberian kecambah kacang kedelai terhadap kadar MDA dan kadar SOD tikus Sprague dawley hiperkolesterolemia. Metode: Penelitian eksperimental laboratorium dengan rancangan post test only controlled grup design. Sampel penelitian adalah 30 ekor tikus Rattus norvegicus galur Sprague Dawley jantan dengan usia tikus 8-10 minggu yang dibagi ke dalam 5 kelompok. Kelompok I adalah tikus normal tanpa perlakuan; kelompok II adalah tikus hiperkolesterolemia tanpa perlakuan; kelompok III adalah tikus hiperkolesterolemia dengan perlakuan kecambah kacang kedelai 0,53 g; kelompok IV adalah tikus hiperkolesterolemia dengan perlakuan kecambah kacang kedelai 1,06 g; kelompok V adalah tikus hiperkolesterolemia dengan
\end{abstract}


perlakuan kecambah kacang kedelai 2,12 g dan semua kelompok diberi perlakuan selama 4 minggu. Hasil: Setelah 4 minggu perlakuan, terjadi penurunan kadar MDA pada kelompok tikus hiperkolesterolemia. Dosis pemberian kecambah kacang kedelai $2,12 \mathrm{~g} /$ hari merupakan dosis paling efektif yang ditunjukkan adanya perbedaan yang signifikan $(\mathrm{p}<0,05)$ antara kelompok perlakuan pertama dengan kelompok perlakuan ketiga. Analisis statistik terhadap kadar SOD menunjukkan perbedaan yang bermakna di semua kelompok perlakuan $(\mathrm{p}<0,05)$. Dosis pemberian kecambah kacang kedelai $2,12 \mathrm{~g} /$ hari terbukti efektif terhadap peningkatan kadar SOD yang ditunjukkan dengan adanya perbedaan yang signifikan $(\mathrm{p}=0,004)$ antara kelompok perlakuan pertama $\left(\mathrm{X}_{1}\right)$ dengan kelompok perlakuan ketiga $\left(\mathrm{X}_{3}\right)$. Simpulan: Dosis kecambah 2,12 g adalah dosis optimal dalam mencegah peningkatan kadar MDA dan membantu meningkatkan kadar SOD tikus Sprague dawley hiperkolesterolemia.

KATA KUNCI: hiperkolesterolemia; kadar MDA; kadar SOD; kecambah kacang kedelai

\section{PENDAHULUAN}

Hiperkolesterolemia merupakan salah satu faktor risiko mayor penyakit jantung koroner. World Health Organization (WHO) memperkirakan hiperkolesterolemia berkaitan dengan lebih dari separuh kejadian penyakit jantung koroner dan lebih dari empat juta kematian tiap tahunnya (1). American Heart Association (AHA) memperkirakan lebih dari 100 juta penduduk Amerika memiliki kadar kolesterol total lebih dari $200 \mathrm{mg} /$ dl yang termasuk kategori cukup tinggi dan lebih dari 34 juta penduduk dewasa Amerika memiliki kadar kolesterol lebih dari $240 \mathrm{mg} / \mathrm{dl}$ yang termasuk tinggi dan membutuhkan terapi (2). Prevalensi hiperkolesterolemia di Indonesia pada kelompok usia 25-34 tahun adalah $9,3 \%$ dan meningkat sesuai dengan pertambahan usia hingga 15,5\% pada kelompok usia 55-64 tahun. Hiperkolesterolemia umumnya lebih banyak ditemukan pada wanita (14,5\%) dibandingkan pria (8,6\%) (3).

Hiperkolesterolemia merupakan kelainan yang terjadi karena peningkatan kadar kolesterol total, trigliserida, low density lipoprotein-cholesterol (LDL-C), dan penurunan high density lipoprotein-cholesterol (HDL-C) (4). Penyebab hiperkolesterolemia antara lain diet tinggi kolesterol atau tinggi asam lemak jenuh, pertambahan berat badan, proses penuaan, faktor genetik, dan penurunan kadar estrogen pada wanita yang telah menopause (5). Gaya hidup masyarakat yang mulai berubah seperti mengkonsumsi makanan yang tinggi lemak merupakan salah satu faktor risiko penyebab hiperkolesterolemia. Kondisi hiperkolesterolemia dapat menyebabkan dampak negatif seperti peningkatan profil lipid, peningkatan risiko aterosklerosis, dan penyakit kardiovaskular sehingga dibutuhkan adanya pengaturan pola makan yang sehat dan seimbang $(4,5)$.

Konsep food as medicine menjadi salah satu upaya yang banyak mendapat perhatian para klinisi di dunia.
Pemilihan bahan pangan merupakan alternatif yang tepat dalam penatalaksanaan hiperlipidemia $(6,7)$. Kacang kedelai termasuk sumber bahan pangan nabati yang mudah didapat dan harganya murah. Beberapa kelebihan kacang kedelai dibandingkan dengan kacang-kacangan lainnya adalah kandungan antitripsin yang sangat rendah, paling mudah dicerna, dan paling kecil memberi pengaruh flatulensi (5). Nilai gizi dalam kecambah kacang kedelai lebih baik daripada nilai gizi pada biji kacang kedelai karena kecambah kacang kedelai telah mengalami proses perombakan makromolekul sehingga dapat meningkatkan daya cerna. Proses perkecambahan juga dapat menyebabkan pembentukan senyawa tokoferol atau vitamin E (7). Dalam 100 g kecambah kacang kedelai mengandung 40,71 mg isoflavon. Food dietary allowence (FDA) merekomendasikan kecukupan isoflavon pada manusia per hari sebesar $24 \mathrm{mg} /$ hari sehingga dengan kebutuhan yang tercukupi dapat membantu menurunkan hiperkolesterolemia $(8,9)$.

Penelitian menunjukkan bahwa pemberian ekstrak tauge dapat menurunkan ketebalan tunika intima-media aorta yang terpapar hiperkolesterolemia (10). Penelitian juga menunjukkan bahwa proses perkecambahan membuat aktivitas antioksidan pada kecambah kacang kedelai mengalami peningkatan secara signifikan dan aktivitas polisakarida menjadi lebih aktif sehingga dapat memberikan manfaat terhadap kesehatan (11). Konsumsi makanan tinggi lemak yang terjadi di masyarakat dapat menyebabkan terbentuknya radikal bebas sehingga memicu terjadinya stres oksidatif yang berakibat terjadinya akumulasi sel lemak di jaringan adiposit, kerusakan, bahkan kematian sel. Stres oksidatif tersebut dapat mempengaruhi aktivitas fagositosis makrofag peritoneal karena terkait dengan proses inflamasi. Hal ini dapat ditanggulangi dengan penggunaan kecambah kacang kedelai sebagai sumber zat gizi yang mengandung 
antioksidan karena diharapkan mampu menghambat terjadinya lipogenesis dan infiltrasi makrofag pada jaringan lemak (6). Tujuan penelitian ini adalah untuk mengetahui pengaruh pemberian kecambah kacang kedelai terhadap kadar malondialdehid (MDA) dan kadar superoxide dismutase (SOD) tikus Sprague Dawley yang hiperkolesterolemia.

\section{BAHAN DAN METODE}

Penelitian ini merupakan jenis penelitian true experimental design dengan randomisasi yaitu post test only controlled grup yang dilaksanakan pada bulan Oktober - Desember 2015. Subjek dipilih secara random ke dalam kelompok intervensi sebagai variabel bebas untuk selanjutnya dilakukan post test, kemudian masing - masing kelompok diberikan intervensi pemberian kecambah kacang kedelai dengan keluaran adalah kadar MDA serum dan kadar SOD. Penelitian dilaksanakan di Laboratorium Gizi, Pusat Studi Pangan dan Gizi (PSPG) Universitas Gadjah Mada untuk pembuatan kecambah kacang kedelai, pemeliharaan tikus Sprague Dawley, pengambilan sampel, pemeriksaan kadar MDA serum, dan kadar SOD serum.

Sampel penelitian adalah 30 ekor tikus Rattus Novergicus galur Sprague Dawley dengan jenis kelamin jantan berumur 2 bulan. Subjek akan dibagi menjadi 5 kelompok yaitu kelompok I adalah tikus normal dengan pemberian diet standar dan tanpa perlakuan (K-); Kelompok II adalah tikus hiperkolesterolemia dan tanpa perlakuan $(\mathrm{K}+)$; Kelompok III adalah tikus hiperkolesterolemia dengan perlakuan kecambah kacang kedelai 0,53 g $\left(\mathrm{X}_{1}\right)$; Kelompok IV adalah tikus hiperkolesterolemia dengan perlakuan kecambah kacang kedelai 1,06 g $\left(\mathrm{X}_{2}\right)$; dan Kelompok V adalah tikus hiperkolesterolemia dengan perlakuan kecambah kacang kedelai 2,12 g $\left(\mathrm{X}_{3}\right)$. Diagram alur proses penelitian ini secara lengkap dapat dilihat pada

\section{Gambar 1.}

Proses pembuatan kecambah kacang kedelai diawali dengan perendaman kacang kedelai utuh (tidak rusak) menggunakan air bersih dengan perbandingan 1:3 selama 12 jam pada suhu kamar $\left(25^{\circ} \mathrm{C}\right)$. Selanjutnya, kacang kedelai ditimbang sebanyak $800 \mathrm{~g}$ dan diletakkan
Tabel 1. Komposisi ransum tikus

\begin{tabular}{lc}
\hline \multicolumn{1}{c}{ Komponen } & Komposisi (\%) \\
\hline Air & Max 12 \\
Protein kasar & Min 15 \\
Lemak kasar & $3-7$ \\
Serat kasar & Max 6 \\
Abu & Max 7 \\
Kalsium & $0,9-1,1$ \\
Fosfor & $0,6-0,9$ \\
Coccidiostat & + \\
Antibiotika & + \\
\hline
\end{tabular}

di antara karung goni yang terlebih dahulu telah dibasahi kemudian digerminasi pada ruangan gelap selama 48 jam. Selama proses germinasi, kacang kedelai harus terjaga kelembapannya dengan menyiramkan air bersih selama 12 jam sekali. Setelah proses germinasi selesai, kecambah siap dipanen. Sementara untuk proses pembuatan ekstrak kecambah kacang kedelai, kecambah dicuci bersih sebanyak 2 kali menggunakan air bersih, ditimbang, dan dihaluskan dengan alat blender dan dilakukan penyeragaman ukuran dengan homogenizer, selanjutnya diberikan pada hewan coba melalui sonde lambung. Ransum yang diberikan pada percobaan ini yaitu ransum standar ADII merk comfeed yang diberikan secara ad libitum. Komposisi ransum dapat dilihat pada Tabel 1. Pengukuran kadar MDA dan SOD dilakukan sekali pada akhir penelitian dengan menggunakan metode spektofotometer.

Penelitian ini telah memperoleh surat ethical clearance untuk penelitian hewan coba yang diterbitkan oleh Komisi Etik Penelitian Kesehatan (KEPK) Fakultas Kedokteran Universitas Diponegoro Semarang dengan nomor 616/EC/FK-RSDK/2015. Data dianalisis menggunakan uji normalitas data dengan menggunakan uji Saphiro-Wilk. Uji selanjutnya untuk melihat perbedaan variabel dependen antarkelompok menggunakan uji One-way ANOVA yang dilanjutkan dengan uji post hoc Bonferroni untuk melihat perbedaan masing-masing kelompok. Uji Kruskal-Wallis dilakukan untuk melihat perbedaan variabel antarkelompok yang mempunyai data yang tidak berdistribusi normal. Apabila terdapat perbedaan, selanjutnya dilakukan uji Mann-Whitney untuk mengetahui perbadaan variabel antara masingmasing kelompok. 


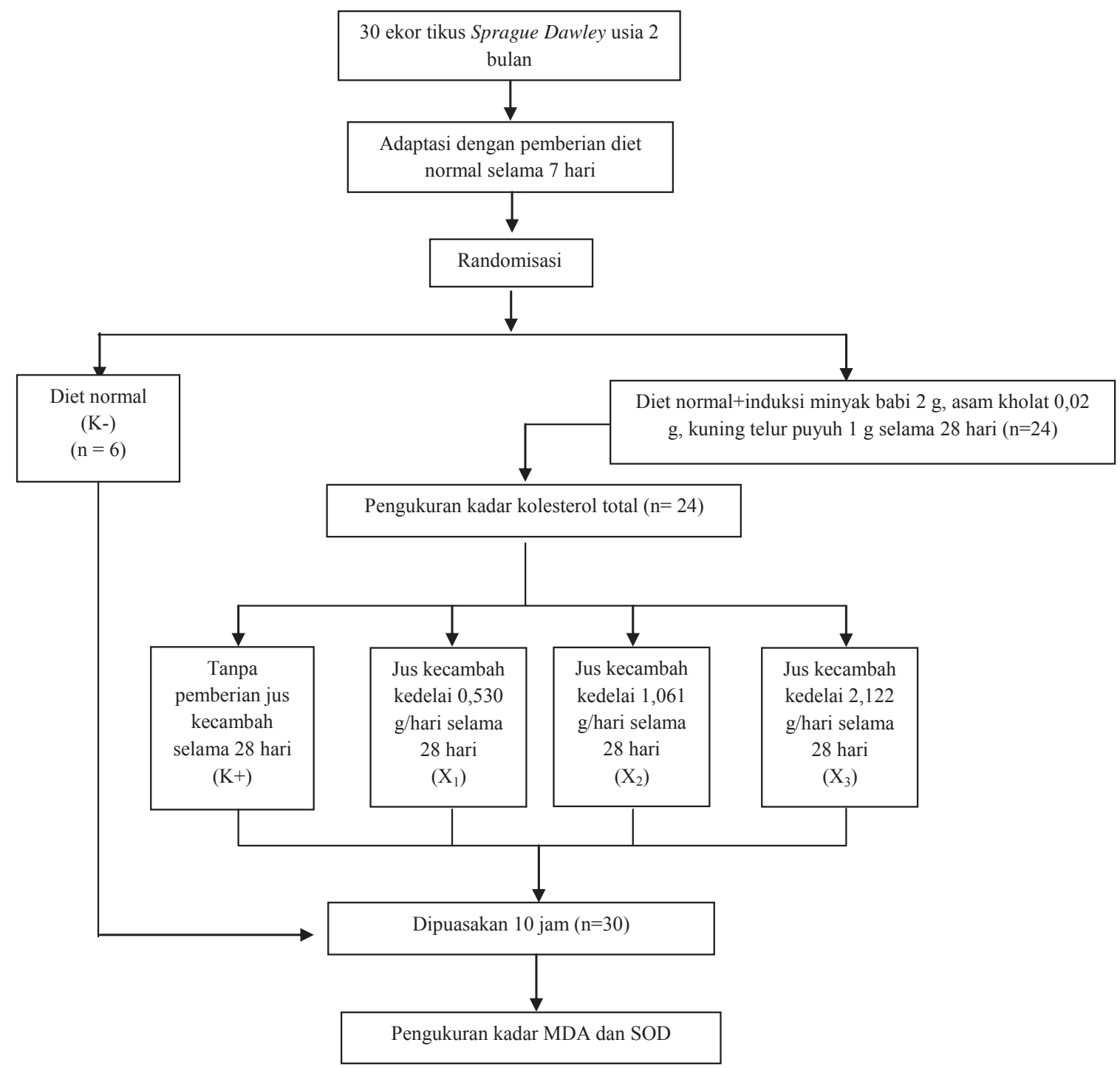

Gambar 1. Diagram alur penelitian

\section{HASIL}

Hasil pengukuran dapat diketahui bahwa kadar MDA memiliki perbedaan antarkelompok yaitu berkisar antara $0,82-7,94 \mathrm{nmol} / \mathrm{ml}$. Hasil uji statistik One-way ANOVA yang dilakukan sesudah perlakuan menunjukkan terdapat penurunan kadar MDA yang signifikan antarkelompok perlakuan $(\mathrm{p}<0,05)$. Kelompok perlakuan $\mathrm{X} 1$ (pemberian kecambah kacang kedelai $0,53 \mathrm{~g}$ /hari) tidak berbeda dengan kelompok perlakuan X2 (pemberian kecambah kacang kedelai 1,06 g/hari). Kelompok perlakuan X2 (pemberian kecambah kacang kedelai $1,06 \mathrm{~g} /$ hari) tidak berbeda dengan kelompok perlakuan
X3 (pemberian kecambah kacang kedelai 2,12 g/hari) (Tabel 2).

Berdasarkan uji Post hoc Bonferroni dapat disimpulkan bahwa pemberian dosis kecambah kacang kedelai $2,12 \mathrm{~g} /$ hari merupakan dosis yang paling efektif, hal ini ditunjukkan pada adanya perbedaan yang signifikan antara kelompok pemberian kecambah kacang kedelai $0,53 \mathrm{~g} /$ hari dengan kelompok yang diberikan kecambah kacang kedelai 2,12 g/hari. Hal ini berarti pemberian dua kali lipat dari dosis yang dibutuhkan berpengaruh nyata terhadap perurunan kadar MDA. Pemberian kecambah kacang kedelai 
Tabel 2. Kadar malondialdehid (MDA) tikus

\begin{tabular}{|c|c|c|}
\hline Kelompok & $\begin{array}{c}\begin{array}{c}\text { Kadar } \mathrm{MDA}^{6} \\
(\mathrm{nmol} / \mathrm{mL})\end{array} \\
\left(\text { Mean } \pm \mathrm{SD}^{7}\right)\end{array}$ & $\mathbf{p}$ \\
\hline Kontrol negatif $(\mathrm{K}-)^{1}$ & $1,20 \pm 0,29$ & 0,000 \\
\hline Kontrol positif $(\mathrm{K}+)^{2}$ & $7,03 \pm 0,54$ & \\
\hline Kelompok perlakuan $1(\mathrm{X} 1)^{3}$ & $5,28 \pm 0,74$ & \\
\hline Kelompok perlakuan $2(\mathrm{X} 2)^{4}$ & $4,21 \pm 0,96$ & \\
\hline Kelompok perlakuan $3(\mathrm{X} 3)^{5}$ & $3,46 \pm 1,30$ & \\
\hline
\end{tabular}

${ }^{1}$ Kelompok kontrol negatif; ${ }^{2}$ Kelompok kontrol positif (hiperkolesterol); ${ }^{3}$ kelompok perlakuan pertama (hiperkolesterol) dengan pemberian kecambah kacang kedelai $0,53 \mathrm{~g} / 200 \mathrm{~g} \mathrm{BB} ;{ }^{4} \mathrm{kelompok}$ perlakuan kedua (hiperkolesterol) dengan pemberian kecambah kacang kedelai $1,06 \mathrm{~g} / 200 \mathrm{~g} \mathrm{BB} ;{ }^{5}$ kelompok perlakuan ketiga (hiperkolesterol) dengan pemberian kecambah kacang kedelai $2,12 \mathrm{~g} / 200 \mathrm{~g} \mathrm{BB} ;{ }^{6} \mathrm{MDA}=$ malondialdehid; ${ }^{7} \mathrm{SD}=$ standar deviasi
Tabel 3. Hasil uji post hoc Bonferroni pada kadar MDA

\begin{tabular}{ccc}
\hline Kelompok hewan coba & & $\mathbf{p}^{\mathbf{a}}$ \\
\hline $\mathrm{K}-$ & $\mathrm{K}+$ & 0,000 \\
& $\mathrm{X}_{1}$ & 0,000 \\
& $\mathrm{X}_{2}$ & 0,000 \\
& $\mathrm{X}_{3}$ & 0,001 \\
$\mathrm{~K}+$ & $\mathrm{X}_{1}$ & 0,014 \\
& $\mathrm{X}_{2}$ & 0,000 \\
& $\mathrm{X}_{3}$ & 0,000 \\
$\mathrm{X}_{1}$ & $\mathrm{X}_{2}$ & 0,385 \\
& $\mathrm{X}_{3}$ & 0,010 \\
$\mathrm{X}_{2}$ & $\mathrm{X}_{3}$ & 1,000 \\
\hline
\end{tabular}

${ }^{a}$ Uji One-way ANOVA

Tabel 4. Kadar superoxide dismutase (SOD) tikus

\begin{tabular}{|c|c|c|}
\hline Kelompok & Kadar SOD6 (unit/ml) $^{6}$ & $\mathbf{p}$ \\
\hline Kontrol negatif $(\mathrm{K}-)^{1}$ & $304,66(300,00-315,25)$ & 0,000 \\
\hline Kontrol positif $(\mathrm{K}+)^{2}$ & $79,23(67,80-177,12)$ & \\
\hline Kelompok perlakuan $1(\mathrm{X} 1)^{3}$ & $133,89(65,25-192,37)$ & \\
\hline Kelompok perlakuan $2(\mathrm{X} 2)^{4}$ & $196,18(119,49-231,36)$ & \\
\hline Kelompok perlakuan $3(\mathrm{X} 3)^{5}$ & $239,14(189,76-278,68)$ & \\
\hline
\end{tabular}

${ }^{1}$ Kelompok kontrol negatif; ${ }^{2}$ Kelompok kontrol positif (hiperkolesterol); ${ }^{3}$ kelompok perlakuan pertama (hiperkolesterol) dengan pemberian kecambah kacang kedelai $0,53 \mathrm{~g} / 200 \mathrm{~g} \mathrm{BB} ;{ }^{4} \mathrm{kel}$ lompok perlakuan kedua (hiperkolesterol) dengan pemberian kecambah kacang kedelai 1,06 g/200 g BB; ${ }^{5}$ kelompok perlakuan ketiga (hiperkolesterol) dengan pemberian kecambah kacang kedelai 2,12 $\mathrm{g} / 200 \mathrm{~g} \mathrm{BB} ;{ }^{6} \mathrm{SOD}=$ superoxide dismutase $;{ }^{7}$ min-maks = nilai minimal - maksimal

sebesar 2,12 g/hari hanya dapat membantu menurunkan kadar MDA, tetapi kadar MDA yang turun masih di atas kadar MDA pada kelompok perlakuan kontrol negative (Tabel 2 dan 3 ).

Hasil pengukuran dapat diketahui bahwa kadar SOD memiliki perbedaan antarkelompok yaitu berkisar antara 65,25 - 315,25 unit/ml. Kadar SOD kelompok perlakuan $3\left(\mathrm{X}_{3}\right)$ 239,14 unit/ml lebih tinggi daripada kelompok tikus kontrol positif $(\mathrm{K}+)$ 79,23 unit/ $\mathrm{ml}$, tetapi lebih rendah daripada kelompok kontrol negatif (K-) 304,66 unit/ml. Hasil uji Kruskall-Wallis menunjukkan bahwa terdapat perbedaan kadar SOD pada lima kelompok $(p<0,05)$ (Tabel 4) dan untuk mengetahui pada kelompok manakah kadar SOD tersebut berbeda, maka dilakukan uji Mann-Whitney (Tabel 5).

Hasil uji statistik Mann Whitney menunjukkan perbedaan kadar SOD pada masing - masing kelompok setelah mendapat perlakuan terdapat perbedaan yang signifikan $(p=0,000)$. Kelompok kontrol positif $(K+)$ tidak menunjukkan perbedaan yang signifikan terhadap kelompok perlakuan pertama $\left(\mathrm{X}_{1}\right)$, hal ini berarti dosis kecambah kacang kedelai yang diberikan pada kelompok perlakuan pertama $\left(\mathrm{X}_{1}\right)$ di bawah kebutuhan normal sehingga hanya sedikit memberikan pengaruh terhadap peningkatkan kadar SOD. Kelompok perlakuan pertama $\left(\mathrm{X}_{1}\right)$ juga tidak menunjukkan perbedaan yang signifikan terhadap kelompok perlakuan kedua $\left(\mathrm{X}_{2}\right)(\mathrm{p}=0,132)$ dan kelompok perlakuan kedua $\left(\mathrm{X}_{2}\right)$ juga tidak menunjukkan perbedaan yang signifikan terhadap kelompok perlakuan ketiga $\left(X_{3}\right)(p=0,065)$. Hal ini berarti perbandingan jumlah dosis yang diberikan pada kelompok perlakuan pertama dan kelompok perlakuan kedua tidak mempengaruhi peningkatan kadar SOD dan dosis yang dapat membantu peningkatan kadar SOD yaitu dosis yang ketiga sebesar $2,12 \mathrm{~g} / 200 \mathrm{~g}$ berat badan tikus. 
Tabel 5. Hasil uji Mann-Whitney pada Kadar SOD

\begin{tabular}{ccc}
\hline Kelompok hewan coba & p \\
\hline $\mathrm{K}-$ & $\mathrm{K}+$ & 0,002 \\
& $\mathrm{X}_{1}$ & 0,002 \\
$\mathrm{X}_{2}$ & 0,002 \\
& $\mathrm{X}_{3}$ & 0,002 \\
$\mathrm{~K}+$ & $\mathrm{X}_{1}$ & 0,310 \\
& $\mathrm{X}_{2}$ & 0,009 \\
& $\mathrm{X}_{3}$ & 0,002 \\
$\mathrm{X}_{1}$ & $\mathrm{X}_{2}$ & 0,132 \\
& $\mathrm{X}_{3}$ & 0,004 \\
$\mathrm{X}_{2}$ & $\mathrm{X}_{3}$ & 0,065 \\
\hline
\end{tabular}

\section{BAHASAN}

Peningkatan konsentrasi MDA membuktikan adanya reaksi lipid peroksida pada tubuh hewan coba (12). Hiperkolestetolemia dalam jangka panjang akan mengakibatkan terjadinya reactive oxygen species (ROS) dan akan muncul radikal - radikal bebas yang dapat meningkatkan stress oksidatif. Produksi ROS yang meningkat dapat mendegradasi lemak tak jenuh ganda membentuk MDA dan mengakibatkan komplikasi. Penelitian sebelumnya menunjukkan hubungan antar kadar MDA yang tinggi dengan hiperkolesterolemia. Kadar MDA pada tikus Sprague Dawley yang diberi diet tinggi lemak lebih tinggi dibandingkan dengan kelompok kontrol. Tingginya kadar MDA disebabkankan oleh ketidakseimbangan jumlah antioksidan baik yang berupa enzim endogen maupun antioksidan dari diet dengan jumlah prooksi dan dapat menyebabkan kondisi stres oksidatif (13). Keadaan hiperkolesterolemia juga menyebabkan ketidakseimbangan antara senyawa oksidatif dan komponen antioksidan endogen sehingga aktivitas antioksidan di dalam tubuh menurun dan akan menyebabkan kerusakan sel, terutama sel hati yang dapat merubah fungsi hati sebagai penetralisir senyawa yang berbahaya. Kadar MDA yang tinggi berhubungan dengan komplikasi hiperkolesterolemia (14).

Pengukuran MDA telah lama digunakan sebagai indikator kerusakan oksidatif pada lemak tak jenuh sekaligus sebagai indikator keberadaan radikal bebas. Hasil penelitian menunjukkan bahwa subjek pada manusia dengan diet tinggi lemak akan mengalami kondisi stres oksidatif yang ditandai oleh radikal bebas yang meningkat dan status kapasitas enzim antioksidan menurun (6). Superoxide dismutase merupakan suatu antioksidan yang berasal dari dalam tubuh yang dapat mengeliminasi radikal superoksida dan melindungi sel dari kerusakan akibat radikal bebas. Superoxide dismutase mengkatalisis perubahan superoksida menjadi hidrogen peroksida $\left(\mathrm{H}_{2} \mathrm{O}_{2}\right)$ (15). Reaksi ini dipercepat oleh SOD dari 104 sampai 109 kali lebih cepat dari pada dismutase spontan sehingga dapat meredam efek radikal bebas superoksida yang terbentuk dalam keadaan fisiologis. Penelitian sebelumnya menunjukkan hubungan antar kadar SOD yang tinggi dengan hiperkolesterolemia. Kadar SOD pada tikus Sprague Dawley yang diberikan suplementasi Zn dan Se mengalami peningkatan (16). Aktivitas antioksidan enzimatis sangat dipengaruhi oleh asupan antioksidan non-enzimatis, aktivitas SOD eritrosit pada kaum pria yang diberi jus tomat selama seminggu meningkat secara signifikan $(p<0,05)(17)$. Peningkatan ini disebabkan oleh kandungan antioksidan likopen yang dapat menghambat terjadinya reaksi oksidasi. Pasienpasien dengan malnurisi (hiperkolesterolemia) akan menyebabkan penurunan enzim glutathione dalam tubuh. Hal ini mengakibatkan keseimbangan antara prooksidan dan antioksidan menjadi terganggu dan terjadi pelepasan nitrit oksida (NO) dan penurunan kadar mikronutrien dalam tubuh yang mengakibatkan sel akan lebih sentitif terhadap stres oksidatif dan terjadi penurunan kadar SOD (18).

Hasil yang diperoleh dari penelitian ini menunjukkan bahwa terdapat korelasi yang kuat antara kadar MDA dan SOD. Semakin tinggi kadar MDA maka semakin rendah kadar SOD tikus. Penurunan kadar MDA dan peningkatan kadar SOD terjadi pada tikus hiperkolesterolemia setelah dilakukan pemberian buah jambu biji merah (19). Kelompok tikus yang diberi pakan lemak tinggi memiliki kadar MDA yang tinggi. Tikus dengan hiperkolesterolemia akan meningkatkan peroksidasi lipid di hati, jantung, dan jaringan ginjal yang ditandai oleh penurunan kadar SOD (20). Dosis optimal $2,12 \mathrm{~g} / 200 \mathrm{~g}$ berat badan tikus) terbukti efektif mencegah peningkatan MDA dan membantu meningkatkan kadar SOD dibandingkan kelompok kontrol atau dosis lain, hal ini dikarenakan kondisi hiperkolesterolemik memaksa tubuh menyimpan persediaan lemak, sehingga akan berdampak pada kenaikan berat badan. Hasil penelitian 
sebelumnya menunjukkan bahwa subyek pada manusia dengan diet tinggi lemak akan mengalami kondisi stress oksidatif, yang ditandai oleh radikal bebas yang meningkat dan status kapasitas enzim antioksidan menurun (6).

\section{SIMPULAN DAN SARAN}

Kadar MDA pada kelompok tikus yang diberi kecambah kacang kedelai lebih rendah dibandingkan pada kelompok tikus hiperkolesterolemia. Kadar SOD pada kelompok tikus yang diberi kecambah kacang kedelai lebih tinggi dibandingkan pada kelompok tikus hiperkolesterolemia. Pemberian dosis kecambah kacang kedelai 2,12 g/200 g BB dapat menurunkan kadar MDA secara efektif dan memberikan peningkatan yang efektif kadar SOD pada tikus jantan Sprague Dawley hiperkolesterolemia. Perlu dilakukan penelitian lebih lanjut tentang pengaruh pemberian kecambah kacang kedelai dan pakan lemak tinggi terhadap antioksidan endogen dalam tubuh misalnya enzim katalase dan glutation peroksidase.

\section{RUJUKAN}

1. Badan Penelitian dan Pengembangan Kesehatan Kementerian Kesehatan Republik Indonesia. Riset Kesehatan Dasar (Riskesdas) tahun 2013. Jakarta: Kemenkes RI; 2013.

2. Acha. National College Health Assessment: reference group executive summary spring 2013. [series online] 2013 [cited Juli 2015]. Available from: URL: http://www. acha-ncha.org/docs/ACHA-NCHA-II_ReferenceGroup_ ExecutiveSummary_Spring2013.pdf.

3. Wignjosoesastro C. Pengaruh bawang putih (Allium sativum) terhadap pencegahan hiperkolesterolemia pada tikus. Damianus J Med 2014;13(1):9-16.

4. Z Chen, R Peto, R Collins, S MacMahon, J Lu, W Li, et al. Serum cholesterol concentration and coronary heart disease in population with low cholesterol concentrations. BMJ 1991;303(6797):276-82.

5. Anggrahini S. Pengaruh lama pengecambahan terhadap kandungan $\alpha$-tofoferol dan senyawa proksimat kecambah kacang hijau (Phaseolus radiatus L.). Agritech 2007;27(4):152-7.

6. Yang RL, Shi YHS, Li W, Le G. Increasing oxidative stress with progressive hyperlipidemia in human: relation between malondialdehyde and atherogenic index. J Clin Biochem Nutr 2008;43(3):154-8.

7. Etkin NL, Ross PJ. Food as medicine and medicine as food. An adaptive framework for the interpretation of plant utilization among the Hausa of Northern Nigeria. Soc Sci Med 1982;16(17):1559-73.

8. Purwono, Hartono. Kacang hijau. Jakarta: Penyebar Swadaya; 2008.

9. Morell SF. Dangers of dietary isoflavones at levels above those found in traditional diets. Food Chem Toxicol 2012;34:45761.

10. Purwandhono A. Pengaruh pemberian ekstrak tauge (Vigna radiata (L)) terhadap kadar kolesterol LDL dan perkembangan aterosklerosis pada tikus Wistar jantan hiperkolesterolemi. [series online] 2014 [cited Juli 2015]. Available from: URL: http://repository.unej.ac.id/handle/123456789/58898

11. Yuan M, Jia X, Yang Y, Dinga C, Dub L, Chena Y, et al. Effect of light on structural properties and antioxidant activities of polysaccharides from soybean sprouts. Process Biochem 2015;50(7):1152-7.

12. Wong ML, Tims RE, Goh EM. Colorimetric determination of total tocopherols in palm oil, olein and stearin. J Am Oil Chem Soc 1988;65;258.

13. Daniels TF, Killinger KM, Michal JJ, Wright RW, Jiang Z. Lipoproteins, cholesterol homeostatis and cardiac health. Int J Biol Sci 2009;5(5):474-88.

14. Lecumberri E, Goya L, Mateos R, Alía M, Ramos S, Bravo $\mathrm{L}$, et al. A diet rich in dietary fiber from cocoa improves lipid profile and reduces malondialdehyde in hypercholesterolemic rats. Nutrition 2007;23(4):332-41.

15. Yasmeen H, Hasnain S. In vitro antioxidant effect of Camellia sinensis on human cell cultures. Pak J Pharm Sci 2015;28(5):1573-81.

16. Ibrahim KS, Saleh ZA, Farrag AR, Shaban EE. Protective effects of zinc and selenium against benzene toxicity in rats. Toxicol Ind Health 2011;26(6):537-45.

17. McIntyre M, Bohr DF, Dominiczak AE. Endothelial function in hypertension: the role of superoxida anion. Hypertension 1999;34(4 Pt 1):539-45.

18. Boaventura BC, Di Pietro PF, de Assis MA, Ambrosi C, Nesello LA, Fausto MA, et al. Antioxidant biomarkers and food intake in elderly women. J Nutr Health Aging 2012;16(1):21-5

19. Maryanto S, Fatimah S, Sugiri S, Marsono Y. The effect of red guava fruits supplementation on the SCFA and cholesterol production in caecum of hypercholesterolemic rats. Agritech 2013;33(3):334-9.

20. Noeman SA, Hamooda HE, Baalash AA. Biochemical study of oxidative stress markers in the liver, kidney and heart of high fat diet induced obesity in rats. Diabetol Metab Syndr 2011;3(1):17. 